\title{
Chicken Neoplasm
}

National Cancer Institute

\section{Source}

National Cancer Institute. Chicken Neoplasm. NCI Thesaurus. Code C135005.

A neoplasm that occurs in a chicken. 